\title{
Feeding Habits of Ctenochromis polli Thys Van Den Audenaerde, 1964 (Labriformes, Cichlidae), From Low Course of Djoue River (Affluent of Right Bank of Congo River)
}

\author{
A. Tsoumou ${ }^{*}$, M. Mikia ${ }^{1}$, I. Mady-Goma Dirat ${ }^{1}$, D. B. C. Olabi-Obath ${ }^{1,2}$, \\ H. Banga-Mboko' ${ }^{2}$ J. Vouidibio ${ }^{3}$
}

\begin{abstract}
${ }^{1}$ Research Laboratory of Animal Biology and Ecology, Normal High School, Marien NGouabi University, Brazzaville, Congo
${ }^{2}$ National High School of Agronomy and Forestry, Marien NGouabi University, Brazzaville, Congo

${ }^{3}$ Faculty of Sciences and Techniques, Marien NGouabi University, Brazzaville, Congo

Email: *anthelmejordy@gmail.com, *clariamulembu@yahoo.fr
\end{abstract}

How to cite this paper: Tsoumou, A., Mikia, M., Mady-Goma Dirat, I., Olabi-Obath, D.B.C., Banga-Mboko, H. and Vouidibio, J. (2019) Feeding Habits of Ctenochromis polli Thys Van Den Audenaerde, 1964 (Labriformes, Cichlidae), From Low Course of Djoue River (Affluent of Right Bank of Congo River). Open Journal of Animal Sciences, 9, 461-471. https://doi.org/10.4236/ojas.2019.94035

Received: September 5, 2019

Accepted: October 26, 2019

Published: October 29, 2019

Copyright $\odot 2019$ by author(s) and Scientific Research Publishing Inc. This work is licensed under the Creative Commons Attribution International License (CC BY 4.0).

http://creativecommons.org/licenses/by/4.0/

\begin{abstract}
The diet of from the lower Djoue River was determined by the size of the specimens and the sampling season. Stomach contents of 662 specimens caught monthly from September 2012 to August 2013 were examined. The size of the individuals varies between 15.37 and $109.52 \mathrm{~mm}$, for a mean $49.95 \pm 8.3$. Of the stomachs analyzed, 145 were empty, representing a vacuity coefficient of $22 \%$. The food spectrum of $C$. polli consists mainly of algaes $(\mathrm{Ip}=65 \%)$ and plant debris $(\mathrm{Ip}=11 \%)$. A plasticity of the diet is observed according to the size, at sizes greater than $69.17 \mathrm{~mm}$ (Classes 5-7), a gradual change in diet was observed with entomophagous and ichthyophagous tendency. The diet varies little according to the seasons; the algaes are the main preys in the dry season and insects during the rainy season. The food composition and the intestinal coefficient value showed that Ctenochromis polli is herbivorous.
\end{abstract}

\section{Keywords}

Ctenochromis polli, Djoue River, Herbivorous

\section{Introduction}

Current knowledge of Haplochrominii in the Congo Basin is scarce, if not totally absent for the majority of species except those living in large lakes [1]. Ctenochromis polli is a highly prolific species on the right bank of Pool Malebo and the lower Djoue River [2] [3] [4] [5]. However, there is no available data on its food 
ecology, although this information is essential for understanding the biology of fish populations [6]. The interest of this study lies in the fact that it shows the existence between the morphology of the digestive tract and the food ecology [7] [8] [9] [10]) and analyses the diet of Ctenochromis polli both qualitatively and quantitatively. In addition, the effect of dietary variation by season and size class was studied.

\section{Materials and Methods}

\subsection{Study Site}

The study was conducted in the lower Djoue River, downstream of the hydroelectric dam. The experimental station is located at the confluence of Djoue River with Mfilou River (Figure 1).

The sampling station is located at the confluence of the Djoue River with the Mfilou River. It is located between $315 \mathrm{~m}$ and $292 \mathrm{~m}$ of altitude; $4.29^{\circ} \mathrm{S}$ and

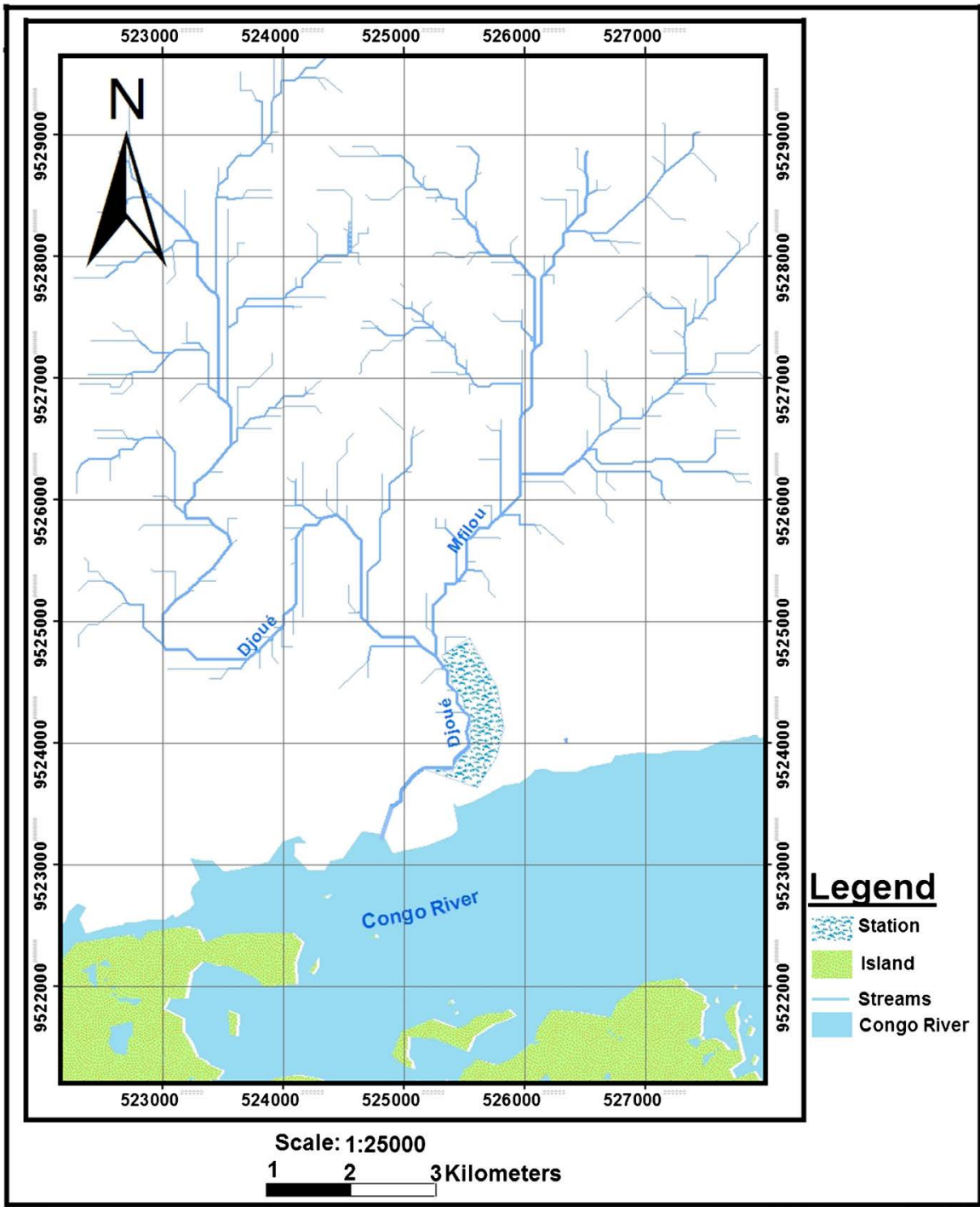

Figure 1. Study site, main channel of Djoue River at the confluence with Mfilou River. 
$4.30^{\circ} \mathrm{S}$ latitude, $15.23^{\circ} \mathrm{E}$ and $15.22^{\circ} \mathrm{E}$ longitude. This station is dominated by Echinochloa pyramidalis.

\subsection{Sampling, Size Classes and Fish Dissection}

Specimens of $C$. polli were caught monthly (September 2012 to August 2013). The standardized sampling technique was the cash net. All captured fishes were fixed with $10 \%$ formalin and stored in 5\% formalin. The standard length and length of the intestine were measured to the millimeter using a Vernier brand caliper and weights (not eviscerated and eviscerated) using an Oaus brand balance to the nearest milligram. Stomach contents are collected, examined and sorted under a Motic brand binocular loupe before being weighted. The identification of preys was made according to keys proposed by various authors [11] [12] [13]. Ingested preys were identified using a binocular microscope to the species level where possible; the excessively weathered remains were classified as the indeterminate group. For each prey, specimens were counted and measured. The fishes were grouped by size class according to the Sturge rule [14]. The number of size classes $(N C)$ and the range of classes $(I C)$ are given by the following relation:

$$
N C=1+\left(3.3 \log _{10} N\right) \text { and } I C=\frac{L S_{\operatorname{maxi}}-L S_{\text {mini }}}{N C}
$$

where $N$ is the number of all specimens examined.

$L S$ is the maximum and minimum standard length.

\subsection{Intestinal Coefficient (Ir)}

The intestinal coefficient ( $I r)$ is the ratio of the length of the intestine to the standard length predicts the diet of a species [15] [16] [17] [18].

It is given by the relation $I r=\frac{L i n t}{L S}$, where Lint is bowel length and $L S$ is standard length in millimeters.

\subsection{Analysis of Stomach Contents}

The following indices were used for the qualitative and quantitative analysis of the diet.

\subsection{Coefficient of Emptiness $(V)$}

This is the ratio expressed as a percentage between the number of empty stomachs $\left(E_{V}\right)$ and the total number of stomachs examined $(N)$. Its relation is:

$$
V=E v / N \times 100 \quad[19]
$$

\subsection{Percentage of Occurrence}

The corrected percentage of occurrence proposed by [20] [21] is given by the relation:

$$
F_{C}=\frac{F_{i}}{\sum F_{i}} \times 100 \text { and } F_{i} \frac{N_{i}}{\sum N_{i}}
$$


where

$N_{i}$ is number of stomachs containing the element $i$;

$F_{i}$ is Frequency of a prey $i$.

\subsection{Percentage of Weight and Preponderance Index}

The weight percentage whose relation is:

$$
P=\frac{P_{i}}{\sum P_{i}}
$$

where

$P i$ is the total weight of a prey.

The preponderance index of [22], gives the relative importance of each category of prey. It combines the corrected percentage of occurrence and the weight percentage:

$$
I p=\frac{F c \times P}{\sum(F c \times P)} \times 100 .
$$

This index varies between 0 and 100 .

where

$$
\begin{aligned}
& I p<10 \text { : accessory preys; } \\
& 10 \leq I p<25 \text { : secondary preys; } \\
& 25 \leq I p<50 \text { : important preys; } \\
& I p \geq 50 \text { : main preys. }
\end{aligned}
$$

\subsection{Schoener Index}

The Schoener similarity index is given by the relation:

$$
S_{x y}=1-0.5\left(\sum\left|P_{x i}-P_{y i}\right|\right) \quad[17]
$$

where $P_{x i}$ and $P_{y i}$ are the relative proportions of prey $(i)$ for specimens of classes $x$ and $y$.

\subsection{Statistical Analyzes}

Statistical analyzes of the results by size classes and seasons were made from two statistical tools: Excel and Statistica-7.1. Statistical tests (student test and ANOVA) were used to check the links between parameters. A Cluster analysis based on Euclidean distance is performed from the Prey Occurrence-Classes size matrix to identify similarities between diets of specimens at different sizes.

\section{Results and Discussion}

\subsection{Description of the External Morphology of the C. polli Digestive Tract}

The very short oesophagus continues with a well developed stomach. Beyond the pyloric region the intestine wraps around itself, describing convolutions, and then becomes rectilinear to the anus. Intestinal coefficient and vacuity coeffi- 
cient of the 662 stomachs of $C$. polli examined, the intestinal coefficients calculated ranged between 5.63 and 8.02; with an average of $6.83 \pm 0.5$. Specimens of C. polli have an intestines length six times longer than the body. This value is predictive of an herbivorous diet [23]. Of 662 stomachs analyzed, 145 stomachs were empty, representing an overall vacuity coefficient of $22 \%$. This coefficient is higher in the dry season (24.61\%) than in the rainy season (18.12\%).

\subsection{Overall Diet}

Twelve types of preys were identified in the 517 full stomachs examined: fish remains (scales, bones and fins), insects (imagos and fats), insect larvaes, nematodes, annelids, trematodes, algaes, plant debris, mud, sand grains and other preys that include all unidentified preys. Two preys were frequently seen in the stomachs: algaes and plants debris with occurrence percentages of $28 \%$ (Figure 2).

Of all these preys, algaes are the main preys of Ctenochromis polli, with a preponderance index equal to $65 \%$ (Table 1).

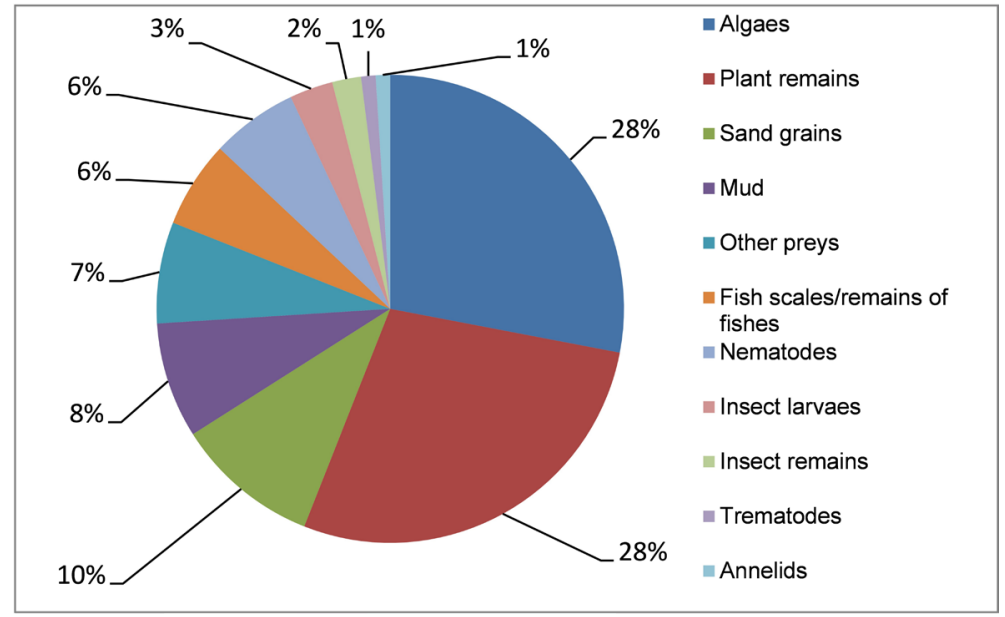

Figure 2. Global food spectrum.

Table 1. Occurrence and preponderance of preys of C. polli.

\begin{tabular}{cccc}
\hline Preys items & Fc & Pc & IP \\
\hline Fish scales/remains of fishes & 6 & 2 & 1 \\
Algaes & 28 & 36 & 65 \\
Plant debris & 28 & 6 & 3 \\
Sand grains & 10 & 4 & 0 \\
Insects & 2 & 3 & 1 \\
Insects larvaes & 3 & 5 & 6 \\
Nematodes & 6 & 17 & 0 \\
Trematodes & 1 & 3 & 0 \\
Annelids & 1 & 0 & 11 \\
Mud & 8 & 21 & 1 \\
\hline
\end{tabular}

Percentage of occurence $\left(F_{\mathcal{C}}\right)$; percentage of weight $\left(P_{\mathcal{C}}\right)$ and preponderance index $(I p)$. 
Plants debris and mud were secondary preys, while all other preys were incidental. In the diet of Ctenochromis polli, there is a clear dominance of algaes. [24] point out, however, that phytoplankton (Diatoms, Cyanophyceae) have been observed frequently in the stomach contents of $H$. (Paralabidochromis) $s p$. Ctenochromis polli has a diet similar to that of $H$. (Paralabidochromis) $s p$. [24]. The diet of this last species is more diversified than that of Ctenochromis polli while remaining mainly insectivorous. It consists of insect larvae and, to a large extent, phytoplankton

\subsection{Variation of the Diet According to the Season}

Despite the seasonal fluctuations of preys available in the environment, the food spectrum consisted of more algaes in the dry season and insects in the rainy season. Figure 3 shows the grouping of preys items by season.

In the rainy season, the rising water provides to fishes a wide range of foods as [25]. The drop of water levels during the dry season, however, seems to have an impact on the availability of food. An ANOVA (Main effects) by the method of speciation (Analysis Winzard) gives the results in Table 2.

At the 95\% threshold ( $\mathrm{p}=0.05$ ), the difference was very significant in the seasonal consumption of the following preys: plants debris, sand grains and mud. The Cichlidae therefore has a larger number of preys at its disposal, so it presents an opportunistic diet, adapting its diet according to available preys that vary qualitatively and quantitatively seasonally. In tropical environments, many studies suggest an abundance of food resources in the rainy season and a reduction in the quantity of these food resources in the dry season [26] [27] [28]. The seasonal fluctuations of available preys in the environment would explain the food spectrum of Ctenochromis polli which consists more of algaes in dry season and insects in rainy season. In the rainy season, the upwelling makes available
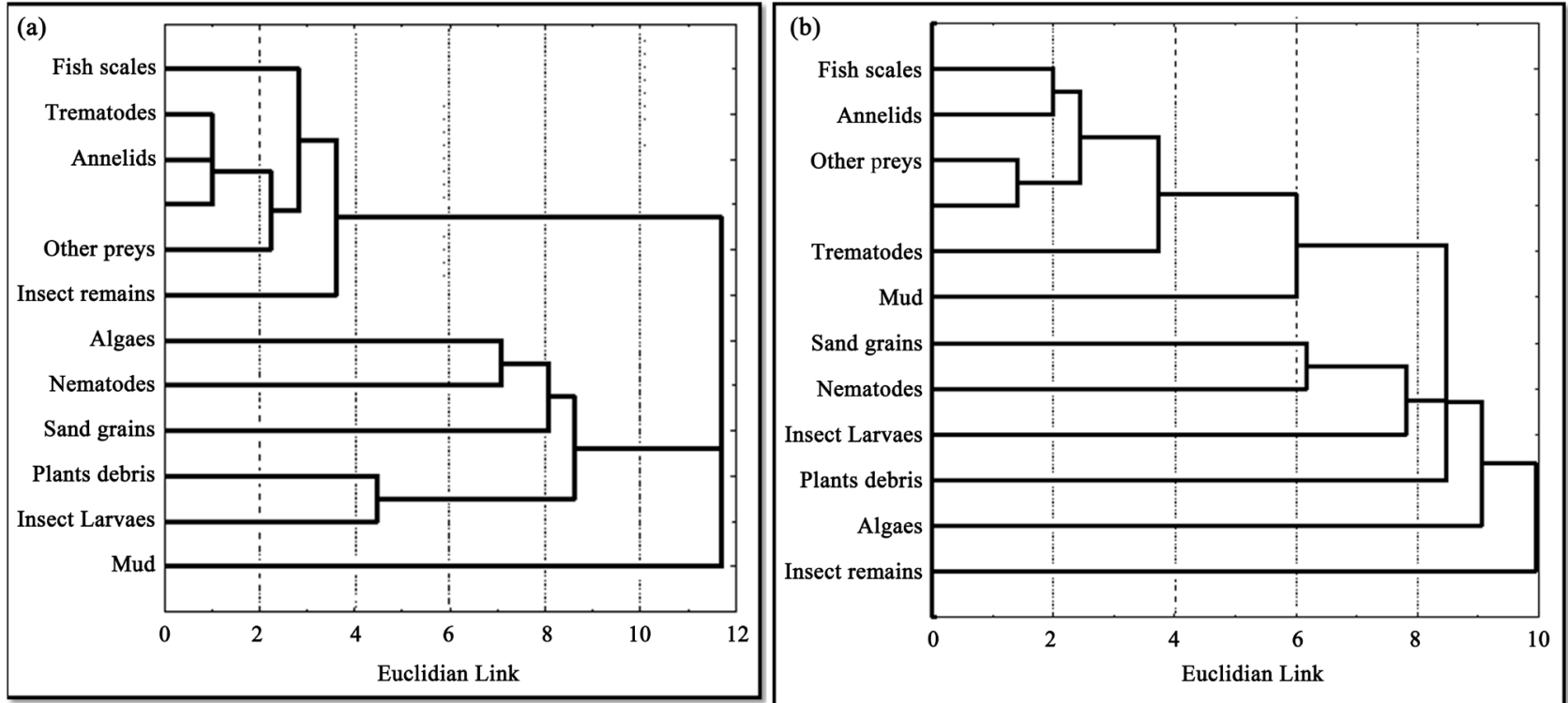

Figure 3. Multidimensional scaling and cluster analysis of items, based on seasons. (a): Dry season; (b): rainy season. 
to the species a wide range of foods as [25]. The drop of water level in dry season, however, seems to have a big impact on food availability.

\subsection{Diet Variation by Size}

The standard length of the specimens studied vary between 15.37 and 109.52 $\mathrm{mm}$. Seven (7) interval classes size 13.45 were defined by the Sturge rule. The modal class is that consisting of specimens whose standard lengths are between 45.27 and $55.72 \mathrm{~mm}$ (Class 4). Table 3 illustrates the quantitative and qualitative changes in the diet of $C$. polli by size.

It appears that the qualitative composition of the food changed during the growth of the fish. Small specimens (Class 1, Class 2 and Class 3 ) have a preference for benthic preys, of plant origin (algaes and plants debris and mud). The consumption of benthic preys is usually accompanied by sand. Class 4 specimens incorporate insects of different stages into their diet. At sizes greater than

Table 2. ANOVA (main effects) by the method of speciation (Analysis Winzard).

\begin{tabular}{|c|c|c|c|c|}
\hline Items preys & Dry season & Rainy season & $\mathbf{F}$ & $p$ value \\
\hline Fish scales/fishes remains & 0.05 & 3.67 & 0.06 & 0.81 \\
\hline Algaes & 44.30 & 61.42 & 3.61 & 0.12 \\
\hline Plants debris & 89.71 & 14.00 & 39.18 & 0.002 \\
\hline Sand grains & 34.71 & 15.00 & 11.57 & 0.02 \\
\hline Insects & 5.76 & 63.67 & 0.45 & 0.53 \\
\hline Insects larvaes & 4.76 & 74.67 & 0.32 & 0.60 \\
\hline Nematodes & 32.19 & 46.67 & 3.45 & 0.12 \\
\hline Trematodes & 1.19 & 9.67 & 0.62 & 0.47 \\
\hline Annelids & 0.19 & 4.67 & 0.20 & 0.67 \\
\hline Mud & 27.43 & 12.00 & 11.43 & 0.02 \\
\hline Other preys & 1.71 & 2.00 & 4.29 & 0.09 \\
\hline
\end{tabular}

Table 3. Weight frequencies of different prey by size classes.

\begin{tabular}{|c|c|c|c|c|c|c|c|c|c|c|c|}
\hline $\begin{array}{c}\text { Preys } \\
\text { Class }[\mathrm{N}]\end{array}$ & $\begin{array}{l}\text { Fish } \\
\text { scales }\end{array}$ & Algaes & $\begin{array}{l}\text { Plants } \\
\text { remains }\end{array}$ & $\begin{array}{l}\text { Sand } \\
\text { grains }\end{array}$ & $\begin{array}{c}\text { Insect } \\
\text { remains }\end{array}$ & $\begin{array}{c}\text { Insect } \\
\text { larvaes }\end{array}$ & Nematodes & Trematodes & Annelids & Mud & $\begin{array}{l}\text { Other } \\
\text { preys }\end{array}$ \\
\hline Class 1 [22] & 0.02 & 0.11 & 0.21 & 0.11 & 0.09 & 0.14 & - & - & - & - & - \\
\hline Class 2 [54] & - & 0.28 & 0.26 & 0.11 & 0.14 & 0.06 & 0.02 & 0.00 & - & 0.09 & 0.03 \\
\hline Class 3 [121] & 0.03 & 0.28 & 0.27 & 0.08 & 0.37 & 0.16 & 0.06 & - & - & 0.03 & 0.02 \\
\hline Class 4 [206] & 0.08 & 0.20 & 0.17 & 0.07 & 0.23 & 0.13 & 0.02 & - & 0.01 & 0.03 & 0.05 \\
\hline Class 5 [79] & 0.25 & 0.07 & 0.07 & 0.07 & 0.14 & 0.14 & 0.07 & 0.07 & - & 0.04 & 0.07 \\
\hline Class 6 [25] & - & - & - & - & 0.33 & 0.67 & - & - & - & - & - \\
\hline Class 7 [10] & 0.50 & - & - & - & 0.33 & 0.17 & - & - & - & - & - \\
\hline
\end{tabular}




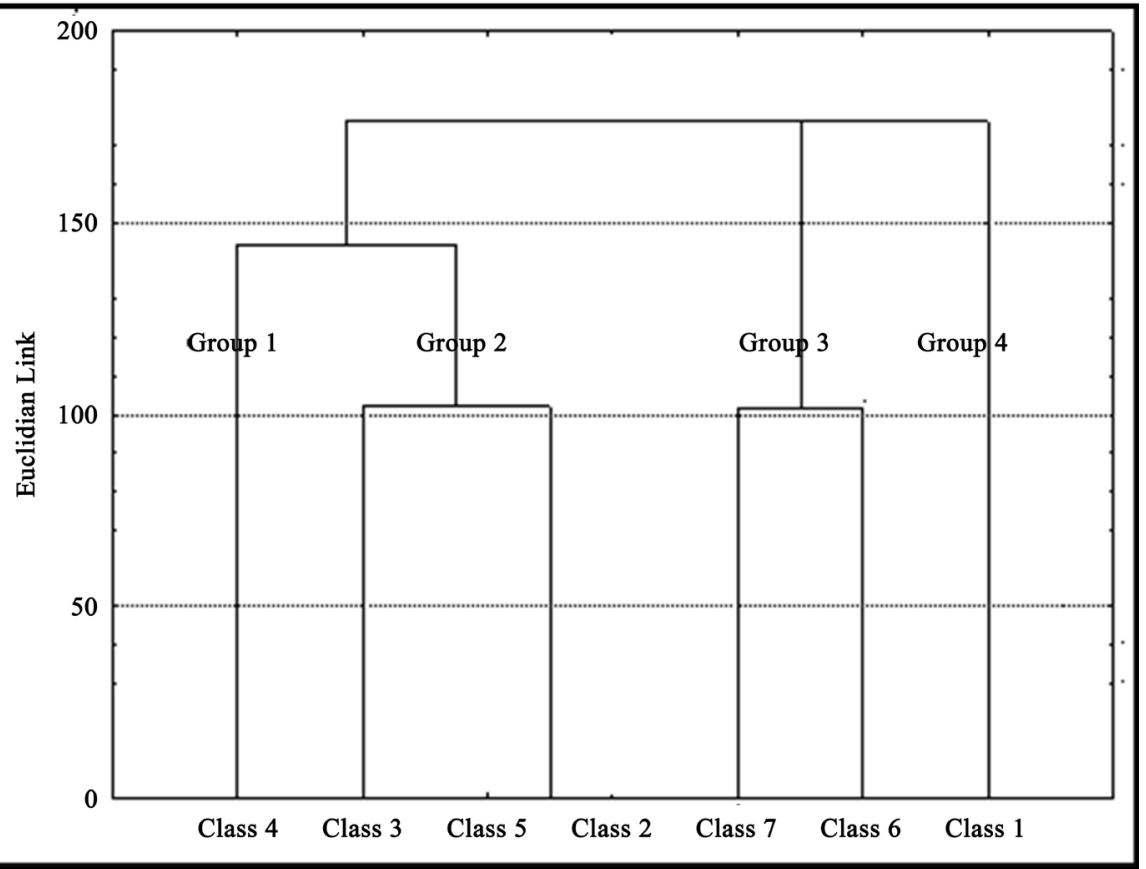

Figure 4. Ascending classification hierarchy of size classes (Cluster analysis).

$69.17 \mathrm{~mm}$ (classes 5 - 7), a gradual change in diet was observed with an entomophagous tendency. The tendency to ichthyophagy or scaliphagia also increased with the size of the fish (from $69.17 \mathrm{~mm}$ ). The same observations were reported by [29] [30] [31] [32], who argue that during fish growth, the qualitative and quantitative composition of food changes. A grouping of prey items in fraction allows to obtain, four fractions: the vegetable fraction, the animal fraction, the sedimentary fraction and the unidentified preys fraction. It seems likely that the sedimentary fraction was collected at the same time as the benthic feed (algaes, plants debris and sand). The same observation is made by [17] [25] [33], these authors also indicate that ingested sand may play a role in shredding food exoskeletons. Larger specimens consume almost no sand and have a preference for animal fractions. The increase in insect preference with fish size may also be related to the ability to consume very mobile and large preys by large specimens [34] [35] believe that this change in diet with fish size is an asset in decreasing competition between small and large specimens. After Cluster analysis of the preys-class size occurrence matrix (Figure 4), four class size groups discriminate at aggregation threshold 120 .

The group 1 consists of specimens from class 4 ; the group 2 makes individuals of classes 2, 3 and 5; the group 3 composed of those of classes 6 and 7, then the group 4 formed mainly specimens of class 1 . On the basis of this grouping of size classes, it appears that the diet of $C$. polli varies according to the size of the specimens.

\section{Conclusion}

The study of the stomach contents of 662 digestive tubes of Ctenochromis polli 
from the Djoue River allows conclure that $C$. polli is an alguivorous with a larvivorous tendency. This diet did not vary according to the hydrological seasons. However, it varies according to the size, the youngest having an alguivorous diet and the adults a larvivorous diet. Several factors could be involved in these observed variations: ecological factors such as nocturnal rhythm, trophic rate, lowering of water levels and availability of prey; biological factors such as sex, reproduction period and environmental factors (water physico-chemistry). It would be interesting to carry out a complementary study of the diet of C. polli taking these different parameters into account.

\section{Conflicts of Interest}

The authors declare no conflicts of interest regarding the publication of this paper.

\section{References}

[1] Ulyel, A.P. (1991) Ecologie alimentaire des Haplochromis spp (Teleostei: Cichlidae) du lac Kivu en Afrique Centrale. Thèse de doctorat, KUL, Leuven, 271 p.

[2] Monsembula Iyaba, R.J.C., Liyandja, T. and Stiassny, M.L.J. (2013) Fishes of the N'sele-River (Pool Malebo, Congo Basin, Central Africa): A List of Species Collected in Main Channel and Affluent Tributaries, Kinshasa Province, Democratic Republic of Congo. Journal of Species Lists and Distribution, Check List, 9, 941-956. https://doi.org/10.15560/9.5.941

[3] Mady-Goma Dirat, I. (2017) Peuplement des poissons de la rive droite du Pool Malébo (Fleuve Congo): Bioécologie de Brycinus comptus (Robert et Stewarz, 1976), Micralestes acutidens (Peters, 1852) et Schilbe intermedius (Rüppel, 1832). Thèse de Doctorat unique, Brazzaville, $442 \mathrm{p}$.

[4] Tsoumou, A., Mady-Goma Dirat, I., Mikia, M. and Vouidibio, J. (2014) Diversity and Spatiotemporal Distribution of the Ichtyofauna of an Urban Natural Environment: Mfilou River, Brazzaville-Congo. Research Journal of Animal, Veterinary and Fishery Sciences, 2, 1-10.

[5] Batiabo Mikembi, A.L., Ibala Zamba, A., Mamonekene, V., Poaty, H.F., Dembi Louvinguila Tenda, H. and Vouidibio, J. (2019) Diversity and Distribution of Fish Species along the Loua River, Lower Congo River Basin (Republic of the Congo, Central Africa). International Journal of Fisheries and Aquatic Studies, 7, 171-176.

[6] Bagenal, T. (1978) Methods for Assessment of Fish Production in Freshwaters. Blackwell Scientific Publications, Oxford, 365 p.

[7] Adite, A. and Winemiller, K.O. (1997) Trophic Ecology and Ecomorphology of Fish Assemblages in Coastal Lakes of Benin, West Africa. Ecosciences, 4, 6-23. https://doi.org/10.1080/11956860.1997.11682371

[8] Bouton, N., Van Os, N. and Witte, F. (1998) Feeding Performance of Lake Victoria Rock Cichlids: Testing Predictions from Morphology. Journal of Fish Biology, 53, 118-127. https://doi.org/10.1111/j.1095-8649.1998.tb01022.x

[9] Hugueny, B. and Pouilly, M. (1999) Morphological Correlates of Diet in an Assemblage of West African Freshwater Fishes. Journal of Fish Biology, 54, 1310-1325. https://doi.org/10.1111/j.1095-8649.1999.tb02057.x

[10] Delariva, R.L. and Agostinho, A.A. (2001) Relationship between Morphology and Diets of Six Neotropical Loricariids. Journal of Fish Biology, 58, 832-847. 
https://doi.org/10.1111/j.1095-8649.2001.tb00534.x

[11] Durand, J.R. and Levêque, C. (1981) Flore et faune aquatique de l'Afrique SahéloSoudanienne Tome 2. Edition ORSTOM, Paris, 392-873.

[12] Gerber, A. and Gabriel, M.J.M. (2002) Aquatic Invertebrates of South African Rivers. Institute of Water Quality Study, $149 \mathrm{p}$.

[13] Gama, G. and Frédéric, F. (2008) Etude de la biodiversité entomologique d'un milieu humide aménagé: Le site du Wachnet, le long du Geer à Waremme (Province de Liège, Belgique). Entomologie faunistique, 1-2, 33-42.

[14] Schereck, C.B. and Moyle, P.B. (1990) Methods for Fish Biology. American Fisheries Society, Bethesda, MD, $684 \mathrm{p}$.

[15] Fryer, G. and Iles, T.D. (1972) The Cichlid Fishes of the Great Lakes of Africa: Their Biology and Evolution. Oliver et Boyd, Edinburgh, Scotland, 641 p.

[16] Paugy, D. (1994) Écologie des poissons tropicaux d'un cours d'eau temporaire (Baoulé, haut bassin du Sénégal au Mali): Adaptation au milieu et plasticité du régime alimentaire. Revue d Hydrobiologie Tropicale, 27, 157-172. https://doi.org/10.4000/books.irdeditions.29211

[17] Kouamelan, E.P., Teugels, G.G., Gourene, G., Thys Van Den Audenaerde, D.F.E. and Ollevier, F. (2000) Habitudes alimentaires de Mormyrops anguillö̈des (Mormyridae) en milieux lacustre et fluvial d'un bassin ouest africain. Cybium, 24, 67-79.

[18] Siaka, B., Essetchi Kouamelan, P., Nahoua, I., Ouattara, V., N’Douba, V. and N'Guessan Kouassi, J. (2008) Régime alimentaire de Distichodus rostratus (Characiformes, Distichodontidae) dans un bassin Ouest africain (fleuve Bandama, Côte d'Ivoire). Science et Nature, 5, 167-176. https://doi.org/10.4314/scinat.v5i2.42162

[19] Schoener, T.W. (1974) Resource Partitioning in Ecological Communities. Science 185, 27-39. https://doi.org/10.1126/science.185.4145.27

[20] Scherrer, B. (1984) Biostatistique. Morin, 850 p.

[21] Rosecchi, E. and Nouaze, Y. (1987) Comparaison de cinq indices utilisés dans l'analyse des contenus stomacaux. Revue des Travaux de P Institut des Pêches Maritimes, 49, 111-123.

[22] Natarajan, A.V. and Jhingran, A.G. (1961) Index of Preponderance-A Method of Grading the Food Elements in the Stomach Analysis of Fishes. Indian Journal of Fisheries, 8, 54-59.

[23] Fermon, Y. (1996) Les Haplochromis spp (Teleostei, Cichlidae) des zones rocheuses du Mwanza Gulf, lac Victoria, Tanzanie: Structure des communautés et écomorphologie. Laboratoire d'Ichtyologie Générale et Appliquée, M.N.H.N., 280 p.

[24] Fourniret, Y., Plisnieri, P.D. and Micha, J.C. (1992) Régime alimentaire de quatre espèces du genre Haplochromis (Teleostéi, Cichlidae) du lac Ihema (Rwanda). Annales de Limnologie, 28, 57-69. https://doi.org/10.1051/limn/1992005

[25] Koné, T., Kouamelan, E.P., Ouattara, N.I. and Kicho, A.V. (2007) Régime alimentaire de Pomadasys jubelini (Pisces, Haemulidae) dans une lagune Ouest Africaine (Lagune Ebrié, Côte d'Ivoire). Sciences \& Nature, 4, 65-73. https://doi.org/10.4314/scinat.v4i1.42131

[26] Matthes, H. (1964) Les poissons du lac Tumba et de la région d'Ikela. Série in $8^{\circ}$ Sciences zoologiques, Tervuren, Belgium, $204 \mathrm{p}$.

[27] Welcomme, R.L. (1995) Relationships between Fisheries and the Integrity of River Systems. Regulated Rivers. Research and Management, 11, 121-136. https://doi.org/10.1002/rrr.3450110110

[28] King, R.P. (1991) The Biology of Tilapia mariae Boulenger, 1899 (Pisces: Cichlidae) 
in a Nigerian Rainforest Stream. University of Port Harcourt, Nigeria, 237 p.

[29] Gharbi, H. and Ktari, M.H. (1981) Biologie de Mullus barbatus Linnaeus, 1758 et Mullus surmuletus Linnaeus, 1758 (Poissons, Téléostéens, Mullidés) des côtes tunisiennes, taille et âge de première maturité sexuelle, cycle sexuel et coefficient de condition. Bulletin de I Institut national scientifique et technique docéanographie et de pêche, 8, 41-51.

[30] Ben-Eliahu, M.N. and Golani, D. (1990) Polychaetes (Annelida) in the Gut Contents of Goatfishes (Mullidae), with New Polychaete Records for the Mediterranean Coast of Israel and the Gulf of Elat (Red Sea). Marine Ecology, 11, 193-205. https://doi.org/10.1111/j.1439-0485.1990.tb00239.x

[31] N’Da, K. (1992) Biologie du rouget de roche Mullus surmuletus (Poisson Mullidae) dans le nord du golfe de Gascogne: Reproducteurs, larves et juvéniles. Thèse de Doctorat. Université Bretagne Occidentale, Brest, France, 177 p.

[32] Pasquad, S., Girardin, M. and Elie, P. (2004) Etude du régime alimentaire des Gobies du genre Pomatoschistus ( $P$. microps et $P$ minustus) dans l'estuaire de la Gironde (France). Cybium, 28, 99-106.

[33] Yatabary, N.T. (1983) Contribution à l'étude du régime alimentaire de Synodontis schall (BlochSchneider, 1801) dans le delta central du fleuve Niger. Revue d Hydrobiologie Tropicale, 16, 277-286.

[34] Harmelin-Vivien, H.L., Kaim-Malka, R.A., Ledoyer, M. and Jakob Abraham, S.S. (1989) Food Partitioning among Scorpaenid Fishes in Mediterranean Seagrass Beds. Journal of Fish Biology, 34, 715-734. https://doi.org/10.1111/j.1095-8649.1989.tb03352.x

[35] Yao, S.S. (2006) Contribution à l'étude de la diversité biologique et de l'écologie alimentaire de l'ichtyofaune d'un hydrosystème ouest africain: Cas du bassin de la Comoe (Côte d'Ivoire). Thèse de Doctorat. Université de Cocody, Abidjan, Côte d'Ivoire, $280 \mathrm{p}$. 